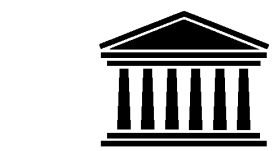 \\ UNIVERSITEIT \\ GENT
}

\section{FACULTEIT ECONOMIE EN BEDRIJFSKUNDE}

\author{
HOVENIERSBERG 24 \\ B-9000 GENT \\ Tel. $\quad: 32-(0) 9-264.34 .61$ \\ Fax. $\quad: 32-(0) 9-264.35 .92$
}

\section{WORKING PAPER}

\section{The Debt-Maturity Structure of Small Firms in a Creditor- Oriented Environment}

\author{
Dries Heyman ${ }^{1}$
}

\author{
Marc Deloof ${ }^{2}$
}

Hubert Ooghe ${ }^{3}$

September 2003

2003/197

We thank Sophie Manigart, Ilse Verschueren, Christof Beuselinck, Eddy Laveren and participants at the 2003 EFMA-meeting in Helsinki for helpful comments and suggestions. The usual disclaimer applies.

\footnotetext{
${ }^{1}$ Corresponding author: Ghent University, Department of Corporate Finance, Kuiperskaai 55E, 9000 Ghent (Belgium), Tel 0032 (0)9 2645307, fax 0032 (0)9 2643577,e-mail: dries.heyman@ugent.be.

${ }^{2}$ Associate professor of Finance, University of Antwerp

${ }^{3}$ Professor, Ernst \& Young Chair of Growth Management and Institute for Credit Management

(Gerling-NCM, Graydon), Vlerick Leuven Gent Management School and Department of Corporate

Finance, Faculty of Economics and Business Administration, Ghent University, Belgium.
} 


\title{
The Debt Maturity Structure of Small Firms in a Creditor Oriented Environment
}

\begin{abstract}
Once a firm decides to issue debt, the characteristics of this debt instrument should be considered. One of the critical decisions involves debt maturity. Using a sample of 1091 Belgian small firms from 1996 until 2000, this study analyses the determinants of the corporate debt-maturity structure of small firms in a creditor-oriented system. Consistent with previous empirical evidence on large firms, the present results strongly support the maturity-matching principle. The hypothesis that firms with many growth opportunities will borrow on the short term as a response to the under-investment problem, is not supported. There is a clear relation between the credit worthiness of a firm and the debt-maturity structure. Firms with a better credit score borrow on the long term, whereas firms with a poor credit quality are apparently forced to borrow on the short term. This evidence contradicts the expected U-shaped relationship between credit worthiness and debt maturity. Size negatively influences debt maturity.
\end{abstract}

Keywords: debt maturity, capital structure, small firms

JEL classification: G32 


\section{Introduction}

As Modigliani and Miller (1958) stated implicitly, and as Stiglitz (1974) demonstrated explicitly, both the capital structure of a firm and debt maturity are irrelevant in perfect capital markets. In other words, decisions concerning the maturity of a debt contracted by a firm can never augment the value of a firm. To prove this, Stiglitz (1974), as well as Modigliani and Miller (1958), made a number of assumptions. These included: (i) the absence of taxes; (ii) that default is not possible; and (iii) that personal lending is equivalent to corporate lending. Several theoretical papers have discussed the influence of so-called imperfections on the corporate debt-maturity structure. Myers (1977) demonstrated the importance of growth opportunities. Other important theoretical contributions have been those of Brick and Ravid (1985, 1991), Diamond (1991, 1993), and Flannery (1986). Empirical evidence has been provided by Guedes and Opler (1996), Barclay and Smith (1995), Stohs and Mauer (1996), Demirgüc-Kunt and Maksimovic (1999), Ozkan (2000), and Scherr and Hulburt (2001)

In the present paper, the determinants of the corporate debt-maturity structure of small firms in a creditor-oriented system are investigated. The present analysis adds to the existing literature in two important ways.

- This is a study of small firms. Most studies of debt-maturity structure have used a sample of large, and often quoted firms. The only previous study to have employed data on small firms appears to have been that of Scherr and Hulburt (2001). Because small firms differ from large firms in several characteristics (for example, ownership structure, flexibility, taxes), their financing options and methods are also quite different. For these reasons, a specific study of the maturity structure of small firms is appropriate.

- The present study uses data from a country with a creditor-oriented system. The only other study also focusing on a creditor-oriented system was that of Cai, Cheun and Goyal (1999) who investigated the determinants of the maturity of public debt issues in Japan. Because they examined public debt issues, their sample also included larger firms. Other authors have focused on listed firms in a market-oriented system (see Guedes and Opler (1996), Barclay and Smith (1995), Stohs and Mauer (1996), and Scherr and Hulburt (2001) for studies in the United States, and Ozkan (2000) for studies in the United Kingdom). This is a significant issue for consideration because it is often argued that banks are better monitors of debt, and can mitigate agency problems. Taken together, these factors influence debt maturity.

The main findings of the present analysis, based on a sample of 4,506 firm-year observations for 1,091 small Belgian firms for the period from 1996 to 2000, are that:

- the maturity-matching principle is the most important determinant of the debt-maturity structure;

- growth options do not seem to influence debt maturity; 
- the better the credit worthiness of a firm, the longer the borrowing period they utilise; and

- larger firms borrow on a shorter term than smaller firms.

The maturity-matching principle has been strongly supported in other empirical work, whereas evidence on the influence of growth opportunities has been mixed. The relationship presented here between credit worthiness and debt maturity is unique in the empirical literature. The empirical evidence on the influence of size has been mixed, with both positive and negative relationships having been reported.

The remainder of the present paper is structured as follows. In Section 2, a concise literature review is provided, and hypotheses are proposed. Section 3 provides information on the sample. Section 4 discusses the variables, and Section 5 discusses the estimation model used in the empirical analysis. In Section 6, the empirical results are presented. Section 7 provides a summarising conclusion to the study.

\section{Literature review and research hypotheses}

\subsection{The choice of debt maturity}

Morris (1976) has argued that firms try to match the maturity of assets and liabilities because this reduces the risk that incoming cash flows might be insufficient to cover interest payments and capital outlays. Debt with a maturity shorter than the maturity of assets is risky because the assets might not have yielded enough profit to repay the debt. Debt with a maturity longer than the maturity of the assets is also risky because debt might have to be repaid after the assets have ceased to yield income. Consequently, firms try to match the maturities of assets and debt. This is known as 'maturity matching'. This leads to the following hypothesis being proposed:

\section{Hypothesis 1: Firms try to match the maturity of assets with that of liabilities.}

According to Myers (1977), reducing debt maturity is an attempt to solve the problem of under investment. He argued that, under debt financing, it is possible that managers might not carry out investments with a positive net present value. When leverage is high, residual claims will be very low and profits from investments will benefit only creditors. Because shareholders will not earn a fair return, they will be reluctant to pursue future investments, which reduces the investment opportunity set and, because firm value equals the value of assets in place and the value of the investment opportunity set, ultimately also reduces firm value. The under-investment problem is of course more severe when a firm has more growth opportunities. Myers (1977) has suggested some solutions to this under-investment problem. One solution consists of reducing the maturity of debt. Issuing debt that matures before an investment opportunity can be carried out will not lead to under investment. Longterm debt is thus best achieved by rolling over short-term debt. This leads to the following hypothesis being proposed:

Hypothesis 2: Firms with high growth opportunities borrow on the short term. 
Other solutions to the under-investment problem are: (i) reducing the amount of debt in the capital structure; or (ii) including restrictive covenants in the debt agreement.

Diamond (1991) focused on the relationship between debt maturity and the credit worthiness of a firm. A key concept in his theory is liquidity risk. Diamond defined liquidity risk as the risk that a debtor will lose control rents because creditors do not want to refinance, and therefore choose to liquidate the firm. Control rents are then defined as the difference between the profits of a project and the payments to the debtor. Because short-term debt was seen by Diamond as being debt that matures before the profits of an investment are received, it is necessary to refinance short-term debt. The possibility of refinancing depends on the willingness of the creditors, which, in turn, depends on the new credit worthiness of the debtor. If refinancing is impossible, assets have to be sold to meet obligations. In this way, part of the control rents are lost. Of course, this has a negative influence on profitability. For firms with a high credit worthiness, the liquidity risk is not relevant. A decrease of their credit worthiness does not lead to a 'crunch' of credit to the firm. For this reason, firms with a high credit rating are expected to borrow on the short term. For firms with a medium credit rating, the liquidity risk can be of importance. If their credit worthiness decreases, creditors could refuse to extend the loan. They might take control of the firm and, perhaps, liquidate it. Firms that are afraid that this might happen borrow on the long term. Firms with a low credit rating also like to borrow on the long term. However, creditors do not want to lend their money on a long-term basis to borrowers of this kind. Firms with a low credit rating are therefore forced to borrow on the short term.

\section{Hypothesis 3: A non monotomous relation exists between credit worthiness and debt maturity. Firms with low and high credit worthiness borrow on the short term, whereas firm with medium credit worthiness borrow on the long term.}

According to Smith and Warner (1979), there is a greater chance of conflicts between shareholders and debtors in smaller firms. Examples are the under-investment problem and the assetsubstitution problem, which occurs when managers invest in more risky assets than that which was originally agreed upon (Barnea, Haugen and Senbet, 1980). In a small firm, the manager usually holds a large proportion of the equity. Actions that benefit the shareholders will therefore also benefit the manager. Because the manager controls the actions of the firm, managers of small firms could be more likely to take risks than managers in large firms. Because these problems can be reduced by issuing short-term debt, a positive relation between firm size and debt maturity is proposed (we admit that firm size is perhaps not the most convenient measure for manager ownership, but we lack better indications on manager ownership) :

\section{Hypothesis 4: There is a positive relationship between size and debt maturity.}

In most cases, the issuing costs of a public debt issue are fixed, and these costs are therefore independent of the magnitude of the debt. This enables economies of scale. For this reason, larger firms are especially likely to issue public debt. Because public debt has a longer maturity than private debt, a positive relation between the size of a firm and the maturity of debt is proposed. However, this 
reasoning does not apply to small unlisted firms, because these firms make very little use of public debt.

The present study also includes leverage and industry affiliation as determinants of debt maturity. Myers (1977) argued that the under-investment problem could also be solved by reducing leverage. It can also be expected that capital structure is, to some extent, sector-dependent.

\subsection{The debt maturity choice for small firms in a creditor-oriented environment}

As noted above, the present study specifically addresses small firms in a creditor-oriented system. The relationship between this sample and the hypotheses (proposed above) is now considered.

\section{Hypothesis 1: Firms try to match the maturity of assets with that of liabilities.}

Small firms are more common in the wholesale, retail, and service sectors, whereas large firms are more common in manufacturing. Because manufacturing involves more fixed investments, the maturity of assets in these (larger) firms is likely to be quite different from that of non-manufacturing (smaller) firms. However, the motive for matching maturity of assets and liabilities continues to be relevant for small firms.

\section{Hypothesis 2: Firms with high growth opportunities borrow on the short term.}

Petit and Singer (1985) argued that debt-related agency problems (such as the under-investment problem) appear to be potentially more serious in smaller firms. This is supported by the fact that smaller firms face more significant problems of asymmetric information-because most small firms do not supply audited financial statements. In addition, smaller firms have more flexibility, which exacerbates problems such as the asset-substitution problem. This suggests shorter debt maturities for small firms. Among others, Berlin and Loeys (1988) have argued that banks are better in monitoring firms than are other lenders. If bank lending does mitigate agency problems, then there could be less need to shorten debt maturity.

\section{Hypothesis 3: A non monotomous relation exists between credit worthiness and debt maturity. Firms with low and high credit worthiness borrow on the short term, whereas firm with medium credit worthiness borrow on the long term.}

An important concept in the theory of Diamond (1991), who proposed the above hypothesis, is that of liquidity risk. To avoid liquidation, firms with a medium creditworthiness will contract longterm debt. However, it can be argued that banks are more willing to renegotiate on contracts than are non-bank lenders (Hoshi, Kashyap, Scharfstein, 1990). If so, liquidity risk decreases for bank borrowers. This induces bank borrowers who have a medium credit worthiness to borrow on a shorter term than non-bank borrowers, for whom liquidity risk is still an important concern.

\section{Hypothesis 4: Size has a positive effect on debt maturity}

Because agency problems are worse in small, owner-managed firms, and because shortening debt maturity is a solution for such agency problems, the present paper argues that a positive relation 
is to be expected between size and debt maturity. However, because the present sample consists entirely of small firms, it is possible that most of these firms are owned by their managers. In this case, the expected relation will not be observed.

\section{Sample}

The data used to construct the sample for the present study were gathered from the Belfirst DVD of Bureau Van Dijk. This DVD is the repository of the annual accounts of the firms that deposit their accounts with the central reserve bank of Belgium. In Belgium, firms with limited liability (irrespective of their size), have a legal duty to deposit their annual accounts in a prescribed format. A distinction is made between firms that have to prepare their annual accounts in a complete format and firms that are allowed to prepare their annual accounts in an abbreviated format. A firm has to use the complete format if it has more than 100 employees or if it satisfies at least two of the following criteria: number of employees (yearly average) of at least 50, turnover (value-added tax excluded) of at least 200 million Belgium Francs (BEF) (4,957,880 Euro (EUR)) and total assets of at least 100 million $\operatorname{BEF}(=2,478,940$ EUR $)$.

The firms in our population had to satisfy the following conditions: (i) be required to deposit an abbreviated account; (ii) have submitted an account in every year from 1996 until 2000; (iii) have at least one employee (because the existence of firms without employees is merely driven by fiscal motivations); and (iv) not belong to the financial sector or governmental sector. Financial firms were excluded because, due to capital requirements, decisions concerning capital and maturity structure could be affected by other factors. Governmental firms were also excluded because, as Smith (1986) has argued, managers in governmental firms have less discretion concerning investments than do managers in non-governmental, and thus, less regulated firms.

From this population, we drew a random sample of 1,200 firms. Observations with missing values were discarded. Outliers were filtered in the following way: (i) the percentage of long-term debt and the percentage of fixed assets could not exceed 100\%; and (ii) the short-term default indicator could not exceed 1. The proxies for growth opportunities were filtered by removing the upper and lower $0.5 \%$ percentile. Thus, a sample of 4,506 firm-year observations from 1,091 firms for the period from 1996 to 2000 was obtained.

\section{Variables}

\subsection{Variable definition}

Guedes and Opler (1996) noted that there are two empirical approaches to investigating the determinants of debt maturity. The first is to investigate the maturity of individual debt issues. However, this approach was problematic with the sample of small firms utilised in the present study because none of the firms made use of public debt issues, and because databases of issues of bank debt 
were not accessible. The second approach involves the use of cumulative data from the annual account, and this was the approach followed here.

Debt maturity was measured in terms of the percentage of total debt outstanding. Amounts payable in more than one year were added to the current portion of amounts payable after one year, and this was divided by the total debt outstanding, with the result being expressed as a percentage. It was therefore calculated as follows:

$\%$ Ltdebt $=\frac{\text { Amounts payable in more than one year }+ \text { Current portion of amounts payable after one year }}{\text { Total debt }}$

Debt that matured within one year but that had an original maturity of more than one year was also included in the measure of long-term debt (because this was issued with a long-term intention). An alternative dependent variable was also specified in which only financial debt was considered. However, results were very similar using this alternative specification.

The maturity of assets was measured by the percentage of total assets that was fixed. ${\text { asset } \text { maturity }_{i}(\text { in } \%)=\frac{\text { fixed } \text { assets }_{i}}{\text { total assets }}}_{i}$

It is very difficult to measure growth opportunities for a sample of non-listed firms. Previous studies using data from listed firms have focused on Tobin's Q as a proxy for growth opportunities. This measure could not be used here because the firms in the present sample were not quoted. Growth opportunities therefore had to be proxied in other ways.

As a first variable, following Scherr and Hulburt (2001), the present study used past growth in total assets. Growth opportunities in a given year were thus calculated as the geometric average of the yearly growth in total assets over the three preceding years. In this approach, it is assumed that firms that grew faster in the past also have greater opportunities for future growth.

Secondly, the ratio of capital expenditures to asset book value was used. Kallapur and Trombley (1999) concluded that, for non-listed firms, this measure best captures ex post realised growth. Growth opportunities in a given year were proxied as the ratio of capital expenditures on asset book value in the same year.

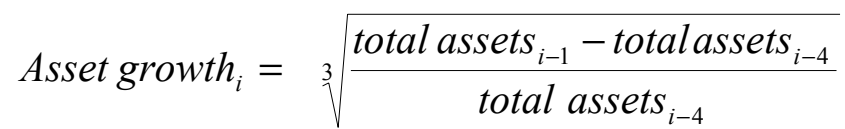

$$
\begin{aligned}
& \text { Capital expenditures }_{i}=\frac{\text { New investments in fixed assets }}{\text { fotal }_{\text {assets }}}
\end{aligned}
$$

Credit worthiness of a firm is often proxied by ratings offered by agencies such as Standard \& Poor's (S\&P) and Moody's. However, none of the firms in the present sample had such a rating. This 
study therefore used a short-term default risk indicator, based on the OJD score, which is a multivariate logit score for failure prediction. This score was developed for Belgian firms as an alternative to the linear Altman's Z score (Ooghe, Joos and de Bourdeaudhuij, 1995). Scores for the short-term default indicator are between 0 (financially healthy firm), and 1 (financially distressed firm).

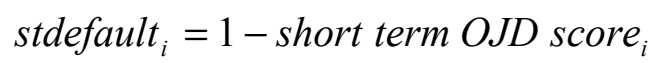

The non monotomous relation between debt maturity and credit worthiness was tested in two ways. First, both STDEFAULT and the square of the STDEFAULT were included as variables. If the relationship between default risk and debt maturity is parabolic, as Diamond (1991) proposed, the coefficient of the default risk should be positive and the coefficient of the square should be negative.

In the second approach, dummies were used to classify the firms into three categories according to their default risk. Firms with a low default risk (high credit worthiness) were taken to be those situated below the 33rd percentile (dumsthi), firms with a medium default risk (and medium credit worthiness) were taken to be those between the $33 \mathrm{rd}$ and 66 th percentile (dumstme). The upper $33 \%$ of the firms were viewed as firms with a high default risk (dumstlo). To avoid the dummy trap, only two of the three dummies could be included in the regression. The sign expected for the different dummies thus depends on the dummies that were entered in the regression.

$$
\begin{aligned}
& \text { dumsth }=1 \text { if stdefault }<0.0425 \\
& \text { dumstme }=1 \text { if } 0.0425 \leq \text { stdefault }<0.1672 \\
& \text { dumstlo }=1 \text { if stdefault }>0.1672
\end{aligned}
$$

Although size can be measured in several ways, the present study used the natural logarithm of total assets and the natural logarithm of added value.

Table 1 presents an overview of the hypotheses, the variables, and the hypothesised signs.

\section{Insert Table 1 about here}

\subsection{Descriptives}

Table 2 depicts descriptive statistics of the variables. On average, $47.7 \%$ of the debt issued was longterm debt, with the median being $46.0 \%$. The average proportion of fixed assets to total assets, at $46.1 \%$, was close to the proportion of long-term debt. Standard deviation of the percentage long-term debt was also remarkably close to the standard deviation of the percentage of fixed assets, with the values being $26.2 \%$ and $27.2 \%$ respectively. This was the first indication that the maturity-matching principle is apposite. Past growth, which was this study's measure of growth opportunities, was fairly high, with the mean being $6 \%$. This figure was twice the median, which amounts to $3 \%$. This indicated the influence of some high-growth firms (which could also be deduced from the maximum, which amounts to $99 \%$ ). The same picture emerged when capital expenditures were used as a proxy for 
growth opportunities. On average, new investments in fixed assets accounted for $7 \%$ of total assets. The median firm spent an amount equivalent to $3 \%$ of total assets.

The average size of the firms in the present sample, measured by total assets, was 756,340 EUR. A very large variance was observed, with the minimum being 13,000 EUR and the maximum being $32,849,000$ EUR. This led to a median that was very different from the average observation of 387.000 EUR. The same conclusion was drawn when examining added value. Firms in the present sample were somewhat smaller than those in the sample of Scherr and Hulburt (2001). They used four subsamples, in which the mean of total assets ranged from $\$ 1$ million to $\$ 2$ million.

The average leverage ratio was $68.7 \%$, and the median was $72.3 \%$. This leverage ratio was substantially higher than in most other empirical studies. This is due to the fact that the present sample was drawn from a banking-oriented environment in which debt is used more frequently. In addition, the measure of leverage used in the present study not only includes financial debt, but also other categories of debt (such as trade debt).

\section{Insert Table 2 about here}

\section{Estimation model}

Because the present data included observations of firms over five years, panel data analysis techniques could be used. Baltagi (1995) has argued that panel data have several benefits. The greatest advantage of panel data to the present study is that they allow control for individual heterogeneity. Panel data suggest that firms are heterogeneous. Because time series and cross-section studies do not control for this heterogeneity, the estimation results could be biased. Panel data analysis allows a consideration of a firm-specific time-invariant effect. The analysis can be run by either a fixed-effects model or a random-effects model. The fixed-effects model can, in general terms, be described by the following equation:

$y_{i t}=\alpha_{i}+\underline{\underline{x_{i t}^{\prime}}} \underline{B}+\varepsilon_{i t}$

in which $\alpha_{i}$ represents an unknown firm-specific constant, which is referred to as a 'fixed effect'.

The alternative, the random-effects model, is described as follows:

$y_{i t}=\alpha+\underline{\underline{x_{i t}^{\prime}}} \underline{B}+\varepsilon_{i t}$

To determine which of these regressions should be run, the Hausman test can be used. This test examines whether the difference between the estimators generated by random-effects regression and the estimators generated by fixed-effects regression approximates zero. In other words: $\mathrm{H}_{0}=$ random effects and $\mathrm{H}_{\mathrm{A}}=$ fixed effects. (In the present analysis $\mathrm{H}_{0}$ was rejected $(p<0.0001)$, which means that the fixed-effects model was to be preferred.) 
As a check for robustness, run pooled OLS-regressions were also run, as were cross-sectional OLS-regressions (in which the observations were the time-series means of the different firms).

\section{Results}

\subsection{Correlations}

Table 3 shows the correlations among the various variables. These results again demonstrate preliminary evidence of the significance of the matching principle - in that the correlation between the maturity of assets and the percentage of long-term debt equalled $62 \%$ (which was statistically significant at the $1 \%$ level). The correlation between the credit worthiness of the firm and the percentage of long-term debt was very slightly positive (but this was not significant). The variables measuring growth opportunities of a firm correlated negatively with the percentage of long-term debt, which is in line with the findings of Myers (1977). Asset growth was significant at the 5\% level, whereas capital expenditures were not significant. There was a very low (and insignificant) positive correlation between total assets and long-term debt, whereas the correlation between added value and long-term debt was strongly negative, and very significant. Because both these measures attempt to capture the size of a firm, no clear picture emerged from this analysis.

\section{Insert Table 3 about here}

\subsection{Regression results}

\subsubsection{Fixed-effects regression results}

Table 4 depicts the results of the fixed-effects regressions. Hypothesis 1 (which proposed that firms seek to match the maturities of assets and liabilities) was strongly confirmed. In every regression, the MATACT coefficient was significant at the $1 \%$ level. Maturity matching was undoubtedly the most important factor in choosing between short-term and long-term debt.

\section{Insert Table 4 about here}

Myers' hypothesis - that firms with significant growth opportunities borrow on the short termwas not confirmed. The coefficients of past growth in assets (regression (1)) and capital expenditures (regression (2)) were not significant. Growth options, and the associated under-investment problem, do not seem to have influenced decisions concerning corporate debt maturity. However, caution is required before rejecting the under-investment hypothesis. It is doubtful whether past growth is a good measure of future growth options.

The coefficient of STDEFAULT (the measure of credit worthiness in this study) was significantly negative, whereas the square of this variable had a significant positive coefficient. This was not in accordance with Hypothesis 3, which predicted a non monotomous, U-shaped relation between debt maturity and credit worthiness-whereby good and bad firms borrow on the short term, 
whereas firms of medium quality borrow on the long term. Figure 1 graphically shows the empirical relationship.

\section{Insert Figure 1 about here}

The relation was U-shaped. However, the lowest value on the parabolic curve is situated at minus the coefficient of the variable divided by two times the square of this coefficient. In all the regressions, this figure was higher than $60 \%$. Because most of the observations were below this level (with the 95\% percentile being situated at a stdefault value of 0.55 ), it can be concluded that the debt maturity was a constantly increasing function of credit worthiness. This was confirmed by the coefficients of the dummy variables used to classify the firms according to their credit rating (regression (4)). The firms belonging to the category with the highest credit score clearly borrowed on a longer term. The firms with a low credit score borrowed more on the short term. Either way, there was no evidence for the non monotomous relation between credit score and debt maturity, as proposed by Diamond (1991).

The final hypothesis proposed a positive relation between size and debt-maturity structure. The results contradicted this proposition (but confirmed the results of Scherr and Hulburt (2001) for American small firms). The first proxy, the natural logarithm of total assets, yielded a negative coefficient which was highly significant at the $1 \%$ level (regressions (1) and (2)). Using the alternative variable, the natural logarithm of value added, the coefficient was insignificant (regression (4)).

Leverage, as a control variable, yielded a statistically significant positive coefficient, and was therefore shown to exert a positive influence on debt maturity. Higher indebted firms might have borrowed on the longer term to ensure that they had earned enough money to be able to repay the creditors. Because the industry to which a firm belongs is time-invariant, these dummies could not be used as a control variable in a fixed-effects regression.

\subsubsection{Robustness}

To check whether the results were dependent on the regression methodology used, the results of the pooled regressions (Table 5) and the cross-sectional regression (Table 6) were analysed. Again, the maturity matching principle was supported strongly. The coefficients were positive and significant. There is no doubt that maturity matching was very important. Consistent with the results of the fixedeffects regression, growth opportunities do not seem to have played a role in determining the debtmaturity structure. When growth opportunities were measured as past growth in total assets, the coefficients had the expected negative sign, but they never reached a significant level. When capital expenditures were used, coefficients were also negative and sometimes reached the $10 \%$ significance level. However, this evidence was too weak to conclude that growth options determined the corporate debt-maturity structure. 
The relationship between credit worthiness and debt maturity also appeared to be very robust in the applied methodology. For each approach, a positive relationship was deduced - that is, financially healthy firms were able to borrow on the longer term, whereas firms with a weak financial condition were forced to borrow on the short term. Diamond's (1991) U-shaped relation was never supported in the present analyses.

The final hypothesis proposed that size has a positive influence on debt maturity. On the basis of the alternative regression used here, support was again found for a negative relation-in that the coefficients were negative and statistically significant for both total assets and added value.

A closer analysis of the industry dummies revealed that wholesale and catering firms appeared to have borrowed on the shorter term. This result was obtained in both the pooled and the crosssectional regression. Because wholesale and catering firms do not produce goods, they can be expected to own relatively few fixed assets. Assuming that they matched the maturity of their assets and liabilities, this could explain their shorter debt maturity.

\section{Insert Table 5 and Table 6 about here}

\subsubsection{Comparison with earlier work}

Although comparison with earlier empirical studies is difficult (due to the different environments and samples involved), it is nevertheless worthwhile to consider similarities and dissimilarities with earlier empirical work. An important observation is that, no matter what kind of firm, or which environment, maturity matching is very important. All studies of which the present authors are aware have found strong evidence for maturity matching.

In contrast, the evidence with respect to growth opportunities is mixed, and seems to vary with the size of the firms that are studied. Consistent with Scherr and Hulburt (2001), the present study found no evidence in support of the growth opportunities hypothesis for small firms. This could be interpreted as evidence that banks are good monitors, so that agency problems do not have to be solved by reducing debt maturity. This is a very plausible explanation in the context of our Belgian system. Most small firms tend to take loan agreement with a local office of their bank. So, these small firms are very like to be closely monitored by these local offices.

Empirical evidence on large firms has been more supportive of the growth opportunities hypothesis. Barclay and Smith (1995), Guedes and Opler (1996), and Ozkan (2000) all found a negative relation between growth opportunities and debt maturity. Stohs and Mauer (1996) also reported this relation. However, after controlling for leverage, the growth opportunities coefficient was not significant in the present study.

Most studies have indicated that credit worthiness influences debt maturity. Barclay and Smith (1995) and Stohs and Mauer (1996) both supported Diamond's (1991) hypothesis for large firms, 
whereas Guedes and Opler (1996) concluded that large US firms with a high credit worthiness borrow on the short term, and Scherr and Hulburt (2001) found that small US firms with lower default risk borrow on the shorter term. This contradicts the present findings, which indicated a positive relation between credit worthiness and debt maturity. Because of the high risk, banks will not lend money on the long term to weak debtors. The finding that good firms borrow on the long term is consistent with that of Graham and Harvey (2001). In their survey of corporate financial policies, issuing long-term debt to minimise the risk of having to refinance in "bad" times is the second most important factor affecting a choice between short-term and long-term debt (with maturity matching being the most important factor).

A positive relation between size and debt maturity was reported by Barclay and Smith (1995) and by Stohs and Mauer (1996). Guedes and Opler (1996) and Scherr and Hulburt (2001) found a negative relation. The present evidence supports the latter findings. As Scherr and Hulburt (2001) have argued, this mixed evidence on size could be caused by the fact that size proxies for several variables (such as agency problems, asymmetric information, etc.).

\section{Conclusion}

In this study, four hypotheses concerning the determinants of debt maturity structure were tested in a sample of small firms in a creditor-oriented environment. The major concern of the firms in this sample seems to have been matching the maturity of assets and liabilities. The maturity-matching principle was very strongly supported. Myers' (1977) hypothesis, suggesting that firms with many growth opportunities will borrow on the short term as a response to the under-investment problem, was not supported by the present study. There is a clear relation between the credit worthiness of a firm and the debt-maturity structure - whereby firms with a better credit score borrowed on the long term, whereas firms with a poor credit quality were apparently forced to borrow on the short term. The size of a firm plays a role that is in direct contrast to what might be expected from the theoretical literature- that larger firms borrow more on the short term. The present findings concerning maturity matching, growth opportunities, and size are fairly much in line with earlier empirical work. The relation found here between credit worthiness and debt maturity has not been previously reported.

\section{References}

Baltagi, 1995, Econometric Analysis of Panel Data, John Wiley \& Sons, p. 275.

Barclay, M. J. \& Smith Jr, C. W., 1995, "The maturity structure of corporate debt", Journal of Finance, vol. 50, no. 2, pp. 609-631.

Barnea, A., Haugen, R. A., \& Senbet, L. W., 1980, "a rationale for debt maturity structure and call provisions in the agency theoretic framework", Journal of Finance, vol. 35, no. 5, pp. 1223-1234.

Berlin M. \& Loeys J., 1988, "Bond covenants and delegated monitoring”, Journal of Finance, vol. 43, pp. 397-412.

Brick I. E. \& Ravid, S. A., 1985, "On the relevance of debt maturity structure", Journal of Finance, vol. 40, no. 5, pp. 1423-1437.

Brick I. E. \& Ravid, S. A., 1991, "Interest rate uncertainty and the optimal debt maturity structure", Journal of Financial and Quantitative Analysis, vol. 26, no. 1, pp. 63-81. 
Cai J, Cheun S. \& Goyal V., 1999, "Bank Monitoring and the Maturity Structure of Japanese Corporate Debt Issues", Pacific-Basin Finance Journal, vol. 7, pp. 229-250

Demirgüc-Kunt, A. \& Maksimovic V., 1999, "Institutions, financial markets, and debt maturity", Journal of Financial Economics, vol. 54, pp. 295-336.

Diamond, D. W., 1991, "Debt maturity structure and liquidity risk", The Quarterly Journal of Economics, vol. 106, pp. 709-737.

Diamond, D. W., 1993, Seniority and maturity of debt contracts, Journal of Financial Economics, vol. 33, pp. 341-368.

Flannery M.J., 1986, "Asymmetric information and risky debt maturity choice", Journal of Finance, vol. 61, no. 1, pp. 19-37.

Graham J. \& Harvey C.,2001, 'The theory and practice of corporate finance: evidence from the field", Journal of Financial Economics, vol. 60, no. 1, pp. 187-243.

Guedes, J. \& Opler, T., 1996, "The determinants of the maturity of corporate debt issues", Journal of Finance, vol. 51, no. 1, pp. 1809-1833.

Hoshi T., Kashyap A. \& Scharfstein D., 1990, "The Role of Banks in Reducing the Costs of Financial Distress in Japan”, Journal of Financial Economics, vol. 27, pp. 67-88.

Kallapur S. \& Trombley M., 1999, "The association between investment opportunity set proxies and realized growth"; Journal of Business Finance and Accounting, vol 26, no. 3, pp. 505-519

Modigliani F. \& Miller M.H., 1958, "The cost of capital, corporation finance and the theory of investment", American Economic Review, vol. 48, pp. 261-297.

Morris James R., 1976, "On corporate debt maturity strategies", Journal of Finance, vol. 31, no. 1, pp. 29-37.

Myers S.C., 1977, "Determinants of corporate borrowing", Journal of Financial Economics, vol. 5, pp. 147-175.

Ozkan, A., 2000, "An empirical analysis of corporate debt maturity structure", European Financial Management, vol. 6, no. 2, pp. 197-212.

Ooghe H, Joos P. \& De Bourdeaudhuij C.,1995, "Financial Distress models in Belgium: The results of a decade of empirical research, International Journal of Accounting, vol. 30, pp. 245-247.

Pettit R. \& Singer R., 1985, "Small business finance: a research agenda", Financial Management, Autumn, pp. 47-60.

Smith C.W. Jr. \& Warner J. B., 1979, “On Financial Contracting”, Journal of Financial Economics, vol. 7, pp. 117-161.

Scherr F.C. \& Hulburt H.M.,2001, "The debt maturity structure of small firms", Financial Management, Spring, pp. 8-111.

Stiglitz J., 1974, "On the irrelevance of corporate financial policy", American Economic Review, vol. 15 , pp. 851-866.

Stohs, M. H. \& Mauer, D. C., 1996, "The Determinants of Corporate Debt Maturity Structure", Journal of Business, vol. 69, no. 3, pp. 279-312. 
Table 1: Hypotheses, variables, expected signs

\begin{tabular}{lll}
\hline \multicolumn{1}{c}{ Hypothesis } & \multicolumn{1}{c}{ Variable } & expected sign \\
\hline $\begin{array}{ll}\text { Firms try to match the maturity of assets with that of liabilities } \\
\text { Firms with high growth opportunities borrow on the short term }\end{array}$ & $\begin{array}{l}\text { Maturity assets } \\
\text { Growth assets }\end{array}$ & $\begin{array}{l}\text { positive } \\
\text { negative }\end{array}$ \\
$\begin{array}{lll}\text { The relationship between the credit worthiness of a firm and } \\
\text { stdefault }\end{array}$ & negative \\
the debt maturity is U shaped & stdefault & positive \\
& In(total assets) & positive \\
Size has a positive effect on debt maturity & In(added value) & positive \\
\hline
\end{tabular}


Table 2: Descriptive statistics of dependent and independent variables

\begin{tabular}{|lrrrrr|}
\hline \multicolumn{1}{|c}{ Variable } & \multicolumn{1}{c}{ Mean } & Std Dev & Minimum & Maximum & Median \\
\hline \%Long term debt $^{\mathrm{a}}$ & 47.7 & 26.2 & 0.0 & 99.8 & 46.0 \\
Asset maturity $^{\mathrm{a}}$ & 46.1 & 27.2 & 0.0 & 1.0 & 43.7 \\
Asset growth $^{\mathrm{a}}$ & 6.4 & 22.8 & -86.2 & 99.3 & 3.8 \\
Capital expenditures $^{\mathrm{a}}$ & 7.6 & 21.7 & 0.0 & 98.8 & 3.4 \\
Short term default $^{\mathrm{a}}$ & 0.2 & 0.2 & 0.0 & 1.0 & 0.1 \\
Total assets $^{\mathrm{b}}$ & 756.3 & 1364.4 & 13.0 & 32849.0 & 387.0 \\
Added value $^{\mathrm{b}}$ & 243.9 & 336.1 & 1.0 & 5138.0 & 126.0 \\
Leverage $^{\mathrm{a}}$ & 68.7 & 21.7 & 1.2 & 99.6 & 72.3 \\
\hline
\end{tabular}

The dependent variable, \%Long-term debt, is the percentage of total debt that was issued with a long-term intention - that is, debt that matures in more than one year plus debt that matures this year but that had an original maturity of more than one year. Asset maturity is the percentage of total assets that are fixed. Asset growth is the geometric average of growth in total assets for the three preceding years (in percentage terms). Capital expenditures is the ratio of capital expenditures this year divided by total assets of this year (in percentage terms). Stdefault is one minus the OJD score (between 0 and 1). Leverage is the ratio between total debt and total assets (in percentage terms).

a Percentage

b Thousands of EUR 
Table 3: Pearson correlation matrix

\begin{tabular}{|c|c|c|c|c|c|c|c|c|c|c|c|c|}
\hline & $\begin{array}{l}\text { Lon } \\
\text { g- } \\
\text { term } \\
\text { debt }\end{array}$ & $\begin{array}{c}\text { Mat } \\
\text { urity } \\
\text { asse } \\
\text { ts }\end{array}$ & $\begin{array}{l}\text { Gro } \\
\text { wth } \\
\text { ass } \\
\text { ets }\end{array}$ & $\begin{array}{l}\text { Ca } \\
\text { pit } \\
\text { al } \\
\text { ex } \\
\text { pe } \\
\text { ndi } \\
\text { tur } \\
\text { es }\end{array}$ & $\begin{array}{l}\text { Stde } \\
\text { fault }\end{array}$ & $\begin{array}{l}\text { Stde } \\
\text { fault } \\
2\end{array}$ & $\begin{array}{l}\text { Dum } \\
\text { sthi }\end{array}$ & $\begin{array}{c}\text { Dum } \\
\text { stm } \\
\text { e }\end{array}$ & $\begin{array}{c}\mathrm{Du} \\
\mathrm{mst} \\
\text { lo }\end{array}$ & $\begin{array}{c}\text { Tot } \\
\text { al } \\
\text { as } \\
\text { set } \\
\text { s }\end{array}$ & $\begin{array}{c}\text { Ad } \\
\text { de } \\
d \\
\text { val } \\
\text { ue }\end{array}$ & $\begin{array}{c}\text { Le } \\
\text { ver } \\
\text { ag } \\
\text { e }\end{array}$ \\
\hline $\begin{array}{l}\text { \%Long term } \\
\text { debt }\end{array}$ & 1.00 & & & & & & & & & & & \\
\hline Asset maturity & $0.62^{* * *}$ & 1.00 & & & & & & & & & & \\
\hline Asset growth & $-0.04^{\star *}$ & -0.06 & 1.00 & & & & & & & & & \\
\hline $\begin{array}{l}\text { Capital } \\
\text { expenditures }\end{array}$ & -0.03 & -0.01 & 0.01 & 1.00 & & & & & & & & \\
\hline Stdefault & 0.01 & $0.34^{\star * *}$ & $-0.09^{* *}$ & 0.01 & 1.00 & & & & & & & \\
\hline Stdefault ${ }^{2}$ & 0.01 & $0.28^{\star * \star}$ & $-0.08^{* *}$ & 0.01 & $0.93^{* \star *}$ & 1.00 & & & & & & \\
\hline Dumsthi & -0.01 & $-0.27^{* * *}$ & $0.06^{*}$ & -0.02 & $-0.52^{* * *}$ & $-0.30^{* * *}$ & 1.00 & & & & & \\
\hline Dumstme & 0.01 & -0.01 & 0.02 & 0.01 & $-0.29^{* * *}$ & $-0.33^{* * *}$ & $-0.54^{* * *}$ & 1.00 & & & & \\
\hline Dumstlo & 0.00 & 0.28 & -0.08 & 0.00 & $0.83^{* * *}$ & $0.66^{* * *}$ & $-0.40^{* * *}$ & $-0.55^{\star \star \star}$ & 1.00 & & & \\
\hline Total assets & 0.01 & $0.11^{* *}$ & -0.05 & 0.02 & $0.10^{* \star *}$ & 0.07 & -0.04 & -0.05 & 0.10 & 1.00 & & \\
\hline Added value & $-0.17^{* * *}$ & $-0.13^{* * *}$ & 0.01 & -0.02 & $-0.08^{* *}$ & $-0.08^{* *}$ & 0.02 & 0.04 & -0.06 & 0.42 & 1.00 & \\
\hline Leverage & -0.04 & 0.07 & -0.07 & 0.00 & $0.35^{* * *}$ & $0.23^{* * *}$ & $-0.46^{* * *}$ & $0.14^{* * *}$ & $0.30^{* * *}$ & -0.05 & -0.08 & 1.00 \\
\hline
\end{tabular}

The dependent variable \%Long-term debt is the percentage of total debt that was issued with a long-term intention - that is, debt that matures in more than one year plus debt that matures this year but that had an original maturity of more than one year. Asset maturity is the percentage of total assets that are fixed. Asset growth is the geometric average of growth in total assets for the three preceding years (in percentage terms). Capital expenditures is the ratio of capital expenditures this year divided by total assets of this year (in percentage terms).Stdefault is one minus the OJD score (between 0 and 1 ), stdefault ${ }^{2}$ is the square of stdefault. Dumsthi is a dummy variable that equals 1 when stdefault score is below 0.0425 , and 0 otherwise. Dumstme is a dummy variable that equals 1 when stdefault score is between 0.0425 and 0.1672 , and 0 otherwise. Dumstlo is a dummy variable that equals 1 if stdefault exceeds 0.1672 . Leverage is the ratio between total debt and total assets (in percentage terms).

* denotes statistical significance at the $10 \%$ level.

** denotes statistical significance at the $5 \%$ level respectively.

$* * *$ denotes statistical significance at the $1 \%$ level. 
Table 4: Results of fixed-effects regressions

\begin{tabular}{|c|c|c|c|c|c|}
\hline Independent variable & $\begin{array}{l}\text { Expected } \\
\text { sign }\end{array}$ & (1) & (2) & (3) & (4) \\
\hline Asset maturity & + & $\begin{array}{c}0.60 \\
(25.62)^{* * *}\end{array}$ & $\begin{array}{c}0.60 \\
(25.63)^{* * *}\end{array}$ & $\begin{array}{c}0.59 \\
(25.48)^{* * *}\end{array}$ & $\begin{array}{c}0.58 \\
(23.32)^{* * *} \\
\end{array}$ \\
\hline Asset growth & - & $\begin{array}{c}-0.00 \\
(-0.43) \\
\end{array}$ & & & $\begin{array}{l}-0.00 \\
(0.35) \\
\end{array}$ \\
\hline Capital expenditures & - & & $\begin{array}{c}0.00 \\
(0.09) \\
\end{array}$ & $\begin{array}{c}0.00 \\
(0.16) \\
\end{array}$ & \\
\hline Stdefault & + & $\begin{array}{c}-0.30 \\
(-6.87)^{* * *} \\
\end{array}$ & $\begin{array}{c}-0.30 \\
(-6.87)^{* * *}\end{array}$ & $\begin{array}{c}-0.30 \\
(-6.81)^{* * *}\end{array}$ & \\
\hline Stdefault $^{2}$ & - & $\begin{array}{c}0.17 \\
(3.10)^{* * *}\end{array}$ & $\begin{array}{c}0.18 \\
(3.11)^{* * *}\end{array}$ & $\begin{array}{c}0.18 \\
(3.11)^{* * *} \\
\end{array}$ & \\
\hline Dumstme & & & & & $\begin{array}{l}-0.03 \\
(-4.12) * * * \\
\end{array}$ \\
\hline Dumstlo & & & & & $\begin{array}{l}-0.07 \\
(-7.42)^{* * *} \\
\end{array}$ \\
\hline Total assets & + & $\begin{array}{c}-0.01 \\
(-2.98)^{* * *}\end{array}$ & $\begin{array}{c}-0.01 \\
(-2.94)^{* * *}\end{array}$ & & \\
\hline Added value & + & & & $\begin{array}{c}-0.00 \\
(-0.86) \\
\end{array}$ & $\begin{array}{c}-0.00 \\
(-0.82) \\
\end{array}$ \\
\hline Leverage & & $\begin{array}{c}0.10 \\
(3.95)^{* * *}\end{array}$ & $\begin{array}{c}0.10 \\
(3.95)^{* * *}\end{array}$ & $\begin{array}{c}0.10 \\
(4.13)^{* * *}\end{array}$ & $\begin{array}{c}0.08 \\
(3.64)^{* * *}\end{array}$ \\
\hline Adjusted $\mathrm{R}^{2}$ & & $77.0 \%$ & $77 . .4 \%$ & $77.1 \%$ & $82.3 \%$ \\
\hline
\end{tabular}

The dependent variable \%Long-term debt is the percentage of total debt that was issued with a long-term intention - that is, debt that matures in more than one year plus debt that matures this year but that had an original maturity of more than one year. Asset maturity is the percentage of total assets that are fixed. Asset growth is the geometric average of growth in total assets for the three preceding years (in percentage terms). Capital expenditures is the ratio of capital expenditures this year divided by total assets of this year (in percentage terms). Ln(Total assets) equals the natural logarithm of total assets, $\ln$ (added value) equals the natural logarithm of added value. Stdefault is one minus the OJD score (between 0 and 1), stdefault ${ }^{2}$ is the square of stdefault. Dumsthi is a dummy variable that equals 1 when stdefault score is below 0.0425 , and 0 otherwise. Dumstme is a dummy variable that equals 1 when stdefault score is between 0.0425 and 0.1672 , and 0 otherwise. Dumstlo is a dummy variable that equals 1 if stdefault exceeds 0.1672 . Leverage is the ratio between total debt and total assets.

$*$ denotes statistical significance at the $10 \%$ level.

$* *$ denotes statistical significance at the 5\% level respectively.

$* * *$ denotes statistical significance at the $1 \%$ level. 
Table 5: Results of pooled regressions

\begin{tabular}{|c|c|c|c|c|c|}
\hline Independent variable & $\begin{array}{l}\text { Expected } \\
\text { sign }\end{array}$ & (5) & (6) & (7) & (8) \\
\hline Intercept & & $\begin{array}{c}0.34 \\
(9.65)^{* * *}\end{array}$ & $\begin{array}{c}0.35 \\
(9.72)^{* * *}\end{array}$ & $\begin{array}{c}0.38 \\
(12.11)^{* * *}\end{array}$ & $\begin{array}{c}0.18 \\
(4.54)^{* * *}\end{array}$ \\
\hline Asset maturity & + & $\begin{array}{c}0.70 \\
(31.10)^{* * *} \\
\end{array}$ & $\begin{array}{c}0.70 \\
(31.21)^{* * *} \\
\end{array}$ & $\begin{array}{c}0.68 \\
(30.35)^{* * *} \\
\end{array}$ & $\begin{array}{c}0.68 \\
(30.30)^{* * *} \\
\end{array}$ \\
\hline Asset growth & - & $\begin{array}{c}-0.05 \\
(-1.17) \\
\end{array}$ & & & $\begin{array}{c}-0.05 \\
(-1.08) \\
\end{array}$ \\
\hline Capital expenditures & - & & $\begin{array}{c}-0.07 \\
(-1.84)^{*}\end{array}$ & $\begin{array}{c}-0.07 \\
(-1.90)^{*}\end{array}$ & \\
\hline Stdefault & + & $\begin{array}{c}-0.61 \\
(-5.40)^{* * *} \\
\end{array}$ & $\begin{array}{c}-0.62 \\
(-5.43)^{* * *} \\
\end{array}$ & $\begin{array}{c}-0.64 \\
(-5.77)^{* * *} \\
\end{array}$ & \\
\hline Stdefault $^{2}$ & - & $\begin{array}{c}0.39 \\
(2.36)^{* * *}\end{array}$ & $\begin{array}{c}0.40 \\
(2.40)^{* * *}\end{array}$ & $\begin{array}{c}0.41 \\
(2.51)^{* * *}\end{array}$ & \\
\hline Dumsthi & & & & & $\begin{array}{l}0.20 \\
(9.59)^{* * *}\end{array}$ \\
\hline Dumstme & & & & & $\begin{array}{l}0.12 \\
(6.41)^{* * *}\end{array}$ \\
\hline Total assets & + & $\begin{array}{c}-0.02 \\
(-4.05)^{* * *} \\
\end{array}$ & $\begin{array}{c}-0.02 \\
(-4.08)^{* * * *} \\
\end{array}$ & & \\
\hline Added value & + & & & $\begin{array}{c}-0.03 \\
(-6.42)^{* * *} \\
\end{array}$ & $\begin{array}{c}-0.03 \\
(-6.12)^{* * *} \\
\end{array}$ \\
\hline Leverage & & $\begin{array}{c}0.01 \\
(0.48) \\
\end{array}$ & $\begin{array}{c}0.01 \\
(0.43) \\
\end{array}$ & $\begin{array}{c}0.04 \\
(1.17) \\
\end{array}$ & $\begin{array}{c}0.05 \\
(1.55) \\
\end{array}$ \\
\hline Dumman & & $\begin{array}{l}0.00 \\
(0.18) \\
\end{array}$ & $\begin{array}{l}0.01 \\
(0.30) \\
\end{array}$ & $\begin{array}{l}0.01 \\
(0.81) \\
\end{array}$ & $\begin{array}{l}0.01 \\
(0.69) \\
\end{array}$ \\
\hline Dumwho & & $\begin{array}{l}-0.04 \\
(-2.39) * * *\end{array}$ & $\begin{array}{l}-0.04 \\
(-2.33)^{* * *}\end{array}$ & $\begin{array}{l}-0.04 \\
(-2.76)^{* * *}\end{array}$ & $\begin{array}{l}-0.04 \\
(-2.70)^{* * *}\end{array}$ \\
\hline Dumret & & $\begin{array}{l}-0.01 \\
(-0.82) \\
\end{array}$ & $\begin{array}{l}-0.01 \\
(-0.60)\end{array}$ & $\begin{array}{l}-0.02 \\
(-1.22)\end{array}$ & $\begin{array}{l}-0.02 \\
(-1.39) \\
\end{array}$ \\
\hline Dumcat & & $\begin{array}{l}-0.06 \\
(-2.56) * * *\end{array}$ & $\begin{array}{l}-0.06 \\
(-2.48) * *\end{array}$ & $\begin{array}{l}-0.05 \\
(-2.12)^{* *}\end{array}$ & $\begin{array}{l}-0.06 \\
(-2.41) * * *\end{array}$ \\
\hline Adjusted $\mathrm{R}^{2}$ & & $49.0 \%$ & $49.1 \%$ & $50.7 \%$ & $49.9 \%$ \\
\hline
\end{tabular}

The dependent variable \%Long-term debt is the percentage of total debt that was issued with a long-term intention - that is, debt that matures in more than one year plus debt that matures this year but that had an original maturity of more than one year. Asset maturity is the percentage of total assets that are fixed. Asset growth is the geometric average of growth in total assets for the three preceding years (in percentage terms). Capital expenditures is the ratio of capital expenditures this year divided by total assets of this year (in percentage terms). Ln(Total assets) equals the natural logarithm of total assets, $\ln$ (added value) equals the natural logarithm of added value. Stdefault is one minus the OJD score (between 0 and 1), stdefault ${ }^{2}$ is the square of stdefault. Dumsthi is a dummy variable that equals 1 when stdefault score is below 0.0425 , and 0 otherwise. Dumstme is a dummy variable that equals 1 when stdefault score is between 0.0425 and 0.1672 , and 0 otherwise. Dumstlo is a dummy variable that equals 1 if stdefault exceeds 0.1672 . Leverage is the ratio between total debt and total assets. Dumman equals 1 if the firm belongs to the manufacturing industry. Dumwho equals one if the firm belongs to the wholesale industry. Dumret equals one if the firm belongs to the retail industry. Dumcat equals one if the firm belongs to the catering industry.

* denotes statistical significance at the $10 \%$ level.

** denotes statistical significance at the $5 \%$ level respectively.

$* * *$ denotes statistical significance at the $1 \%$ level. 
Table 6: Results of cross-sectional regressions

\begin{tabular}{|c|c|c|c|c|c|}
\hline Independent variable & $\begin{array}{c}\text { Expected } \\
\text { sign }\end{array}$ & (9) & (10) & (11) & (12) \\
\hline Intercept & & $\begin{array}{c}0.91 \\
(22.18)^{* * *}\end{array}$ & $\begin{array}{c}0.91 \\
(22.24)^{* * *}\end{array}$ & $\begin{array}{c}0.84 \\
(23.48)^{* * *}\end{array}$ & $\begin{array}{c}0.21 \\
(10.81)^{* * *}\end{array}$ \\
\hline Asset maturity & + & $\begin{array}{c}0.45 \\
(17.53)^{* * *} \\
\end{array}$ & $\begin{array}{c}0.45 \\
(17.53)^{* * *} \\
\end{array}$ & $\begin{array}{c}0.43 \\
(16.63)^{* * *} \\
\end{array}$ & $\begin{array}{c}0.65 \\
(55.58)^{* * *} \\
\end{array}$ \\
\hline Asset growth & - & $\begin{array}{c}0.02 \\
(0.31) \\
\end{array}$ & & $\begin{array}{c}0.01 \\
(0.03) \\
\end{array}$ & \\
\hline Capital expenditures & - & & $\begin{array}{c}-0.03 \\
(-0.69) \\
\end{array}$ & & $\begin{array}{l}-0.03 \\
(-1.92) *\end{array}$ \\
\hline Stdefault & + & $\begin{array}{c}-1.26 \\
(-9.77)^{* * *} \\
\end{array}$ & $\begin{array}{c}-1.27 \\
(-9.84)^{* * *} \\
\end{array}$ & $\begin{array}{c}-1.32 \\
(-10.20)^{* * *} \\
\end{array}$ & \\
\hline Stdefault $^{2}$ & - & $\begin{array}{c}0.95 \\
(5.00)^{* * *} \\
\end{array}$ & $\begin{array}{c}0.95 \\
(5.04)^{* * *} \\
\end{array}$ & $\begin{array}{c}1.01 \\
(5.32) * * *\end{array}$ & \\
\hline Dumsthi & - & & & & $\begin{array}{l}0.16 \\
(16.92) * * *\end{array}$ \\
\hline Dumstme & & & & & $\begin{array}{l}0.09 \\
(12.11)^{* * *} \\
\end{array}$ \\
\hline Total assets & + & $\begin{array}{c}-0.03 \\
(-4.80)^{* * *} \\
\end{array}$ & $\begin{array}{c}-0.02 \\
(-4.80)^{* * *} \\
\end{array}$ & & \\
\hline Added value & + & & & $\begin{array}{c}-0.02 \\
(3.50)^{* * *}\end{array}$ & $\begin{array}{l}-0.03 \\
(-10.79) * * *\end{array}$ \\
\hline Leverage & & $\begin{array}{c}0.02 \\
(0.66) \\
\end{array}$ & $\begin{array}{c}0.02 \\
(0.68) \\
\end{array}$ & $\begin{array}{r}0.045 \\
(1.29) \\
\end{array}$ & $\begin{array}{c}0.03 \\
(1.98)^{* *} \\
\end{array}$ \\
\hline Dumman & & $\begin{array}{l}0.03 \\
(1.92)^{* *}\end{array}$ & $\begin{array}{l}0.04 \\
(1.93)^{* *} \\
\end{array}$ & $\begin{array}{l}0.03 \\
(1.81)^{*} \\
\end{array}$ & $\begin{array}{l}0.01 \\
(1.47) \\
\end{array}$ \\
\hline Dumwho & & $\begin{array}{l}-0.04 \\
(-1.99)^{* *}\end{array}$ & $\begin{array}{l}-0.04 \\
(-2.02)^{* *}\end{array}$ & $\begin{array}{l}-0.05 \\
(-2.62) * * *\end{array}$ & $\begin{array}{l}-0.05 \\
(-5.04) * * *\end{array}$ \\
\hline Dumret & & $\begin{array}{l}0.02 \\
(1.34) \\
\end{array}$ & $\begin{array}{l}0.02 \\
(1.35) \\
\end{array}$ & $\begin{array}{l}0.02 \\
(1.11) \\
\end{array}$ & $\begin{array}{l}-0.02 \\
(-2.04)^{* *}\end{array}$ \\
\hline Dumcat & & $\begin{array}{l}0.00 \\
(0.07) \\
\end{array}$ & $\begin{array}{l}0.00 \\
(-0.08) \\
\end{array}$ & $\begin{array}{l}0.02 \\
(0.56) \\
\end{array}$ & $\begin{array}{l}-0.05 \\
(-3.56)^{* * *}\end{array}$ \\
\hline Adjusted $\mathrm{R}^{2}$ & & $45.21 \%$ & $44.98 \%$ & $45.84 \%$ & $44.74 \%$ \\
\hline
\end{tabular}

The dependent variable \%Long-term debt is the percentage of total debt that was issued with a long-term intention - that is, debt that matures in more than one year plus debt that matures this year but that had an original maturity of more than one year. Asset maturity is the percentage of total assets that are fixed. Asset growth is the geometric average of growth in total assets for the three preceding years (in percentage terms). Capital expenditures is the ratio of capital expenditures this year divided by total assets of this year (in percentage terms). Ln(Total assets) equals the natural logarithm of total assets, $\ln$ (added value) equals the natural logarithm of added value. Stdefault is one minus the OJD score (between 0 and 1), stdefault ${ }^{2}$ is the square of stdefault. Dumsthi is a dummy variable that equals 1 when stdefault score is below 0.0425 , and 0 otherwise. Dumstme is a dummy variable that equals 1 when stdefault score is between 0.0425 and 0.1672 , and 0 otherwise. Dumstlo is a dummy variable that equals 1 if stdefault exceeds 0.1672 . Leverage is the ratio between total debt and total assets. Dumman equals 1 if the firm belongs to the manufacturing industry. Dumwho equals one if the firm belongs to the wholesale industry. Dumret equals one if the firm belongs to the retail industry. Dumcat equals one if the firm belongs to the catering industry.

* denotes statistical significance at the $10 \%$ level.

** denotes statistical significance at the $5 \%$ level respectively.

$* * *$ denotes statistical significance at the $1 \%$ level. 
Figure 1: Empirical relationship between short-term default and debt maturity

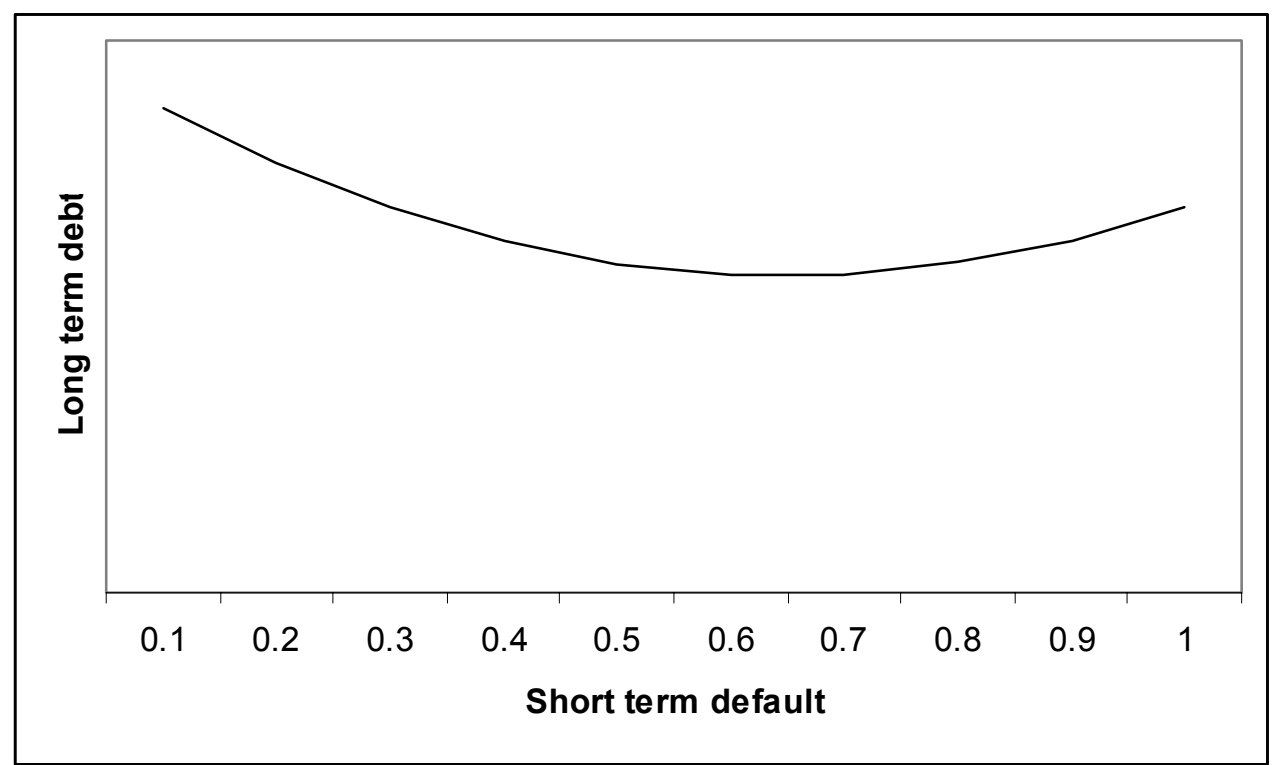

This figure graphically represents the relation between short-term default and the percentage long-term debt, based on the coefficients found in the regression analysis. 
00/80 K. DE WULF, G. ODEKERKEN-SCHRÖDER, The influence of seller relationship orientation and buyer relationship proneness on trust, commitment, and behavioral loyalty in a consumer environment, January 2000, 27p.(published as 'Investments in consumer relationships: a cross-country and cross-industry exploration', Journal of Marketing, 2001)

00/81 R. VANDER VENNET, Cost and profit efficiency of financial conglomerates and universal banks in Europe., February 2000, 33 p. (published in Journal of Money, Credit, and Banking, 2002)

00/82 J. BOUCKAERT, Bargaining in markets with simultaneous and sequential suppliers, April 2000, 23 p. (published in Journal of Economic Behavior and Organization, 2002)

00/83 N. HOUTHOOFD, A. HEENE, A systems view on what matters to excel, May 2000, $22 \mathrm{p.}$

00/84 D. VAN DE GAER, E. SCHOKKAERT, M. MARTINEZ, Three meanings of intergenerational mobility, May 2000,20 p. (published in Economica, 2001)

00/85 G. DHAENE, E. SCHOKKAERT, C. VAN DE VOORDE, Best affine unbiased response decomposition, May 2000, 9 p. (forthcoming in Journal of Multivariate Analysis, 2003)

00/86 D. BUYENS, A. DE VOS, The added value of the HR-department : empirical study and development of an integrated framework, June 2000, 37 p. (published as 'Personnel and human resource managers: Power, prestige and potential - Perceptions of the value of the HR function', in Human Resource Management Journal, 2001).

00/87 K. CAMPO, E. GIJSBRECHTS, P. NISOL, The impact of stock-outs on whether, how much and what to buy, June $2000,50 \mathrm{p}$.

00/88 K. CAMPO, E. GIJSBRECHTS, P. NISOL, Towards understanding consumer response to stock-outs, June 2000, 40 p. (published in Journal of Retailing, 2000)

00/89 K. DE WULF, G. ODEKERKEN-SCHRÖDER, P. SCHUMACHER, Why it takes two to build succesful buyer-seller relationships July 2000, 31 p. (published as 'Strengthening Retailer-Consumer Relationships: The Dual Impact of Relationship Marketing Tactics and Consumer Personality', in Journal of Business Research, 2002)

00/90 J. CROMBEZ, R. VANDER VENNET, Exact factor pricing in a European framework, September $2000,38 \mathrm{p.}$

00/91 J. CAMERLYNCK, H. OOGHE, Pre-acquisition profile of privately held companies involved in takeovers : an empirical study, October 2000, 34 p.

00/92 K. DENECKER, S. VAN ASSCHE, J. CROMBEZ, R. VANDER VENNET, I. LEMAHIEU, Value-at-risk prediction using context modeling, November 2000, 24 p. (published in European Physical Journal B, 2001)

00/93 P. VAN KENHOVE, I. VERMEIR, S. VERNIERS, An empirical investigation of the relationships between ethical beliefs, ethical ideology, political preference and need for closure of Dutch-speaking consumers in Belgium, November 2000, 37 p. (published in Journal of Business Ethics, 2001)

00/94 P. VAN KENHOVE, K. WIJNEN, K. DE WULF, The influence of topic involvement on mail survey response behavior, November 2000, 40 p. (published in Psychology \& Marketing, 2002).

00/95 A. BOSMANS, P. VAN KENHOVE, P. VLERICK, H. HENDRICKX, The effect of mood on self-referencing in a persuasion context, November 2000, 26p. (published in Advances in Consumer Research, vol.28, 2001, p.115-121)

00/96 P. EVERAERT, G. BOËR, W. BRUGGEMAN, The Impact of Target Costing on Cost, Quality and Development Time of New Products: Conflicting Evidence from Lab Experiments, December 2000, 47 p.

00/97 G. EVERAERT, Balanced growth and public capital: An empirical analysis with I(2)-trends in capital stock data, December 2000, 29 p. (forthcoming in Economic Modelling, 2003).

00/98 G. EVERAERT, F. HEYLEN, Public capital and labour market performance in Belgium, December 2000,45 p. (forthcoming in Journal of Policy Modeling, 2004)

00/99 G. DHAENE, O. SCAILLET, Reversed Score and Likelihood Ratio Tests, December 2000, 16 p. 
01/100 A. DE VOS, D. BUYENS, Managing the psychological contract of graduate recruits: a challenge for human resource management, January 2001, 35 p.

01/101 J. CHRISTIAENS, Financial Accounting Reform in Flemish Universities: An Empirical Study of the implementation, February 2001, 22 p.

01/102 S. VIAENE, B. BAESENS, D. VAN DEN POEL, G. DEDENE, J. VANTHIENEN, Wrapped Input Selection using Multilayer Perceptrons for Repeat-Purchase Modeling in Direct Marketing, June 2001, 23 p. (published in International Journal of Intelligent Systems in Accounting, Finance \& Management, 2001).

01/103 J. ANNAERT, J. VAN DEN BROECK, R. VANDER VENNET, Determinants of Mutual Fund Performance: A Bayesian Stochastic Frontier Approach, June 2001, 31 p. (forthcoming in European Journal of Operational Research, 2003)

01/104 S. VIAENE, B. BAESENS, T. VAN GESTEL, J.A.K. SUYKENS, D. VAN DEN POEL, J. VANTHIENEN, B. DE MOOR, G. DEDENE, Knowledge Discovery in a Direct Marketing Case using Least Square Support Vector Machines, June 2001, 27 p. (published in International Journal of Intelligent Systems, 2001).

01/105 S. VIAENE, B. BAESENS, D. VAN DEN POEL, J. VANTHIENEN, G. DEDENE, Bayesian Neural Network Learning for Repeat Purchase Modelling in Direct Marketing, June 2001, 33 p. (published in European Journal of Operational Research, 2002).

01/106 H.P. HUIZINGA, J.H.M. NELISSEN, R. VANDER VENNET, Efficiency Effects of Bank Mergers and Acquisitions in Europe, June 2001, 33 p.

01/107 H. OOGHE, J. CAMERLYNCK, S. BALCAEN, The Ooghe-Joos-De Vos Failure Prediction Models: a CrossIndustry Validation, July 2001, 42 p.

01/108 D. BUYENS, K. DE WITTE, G. MARTENS, Building a Conceptual Framework on the Exploratory Job Search, July 2001, $31 \mathrm{p}$.

01/109 J. BOUCKAERT, Recente inzichten in de industriële economie op de ontwikkelingen in de telecommunicatie, augustus 2001, 26 p. (published in Economisch en Sociaal Tijdschrift, 2001).

01/110 A. VEREECKE, R. VAN DIERDONCK, The Strategic Role of the Plant: Testing Ferdows' Model, August 2001,31 p. (published in International Journal of Operations and Production Management, 2002)

01/111 S. MANIGART, C. BEUSELINCK, Supply of Venture Capital by European Governments, August 2001, 20 p.

01/112 S. MANIGART, K. BAEYENS, W. VAN HYFTE, The survival of venture capital backed companies, September 2001, 32 p. (published in Venture Capital, 2002)

01/113 J. CHRISTIAENS, C. VANHEE, Innovations in Governmental Accounting Systems: the Concept of a "Mega General Ledger" in Belgian Provinces, September 2001, 20 p. (published in V. Montesinos and J.M. Vela, Innovations in governmental accounting, Kluwer Academic Publishers, 2002).

01/114 M. GEUENS, P. DE PELSMACKER, Validity and reliability of scores on the reduced Emotional Intensity Scale, September 2001, 25 p. (published in Educational and Psychological Measurement, 2001)

01/115 B. CLARYSSE, N. MORAY, A process study of entrepreneurial team formation: the case of a research based spin off, October 2001, 29 p.

01/116 F. HEYLEN, L. DOBBELAERE, A. SCHOLLAERT, Inflation, human capital and long-run growth. An empirical analysis, October 2001, $17 \mathrm{p}$.

01/117 S. DOBBELAERE, Insider power and wage determination in Bulgaria. An econometric investigation, October 2001, 30 p. (forthcoming in International Journal of Manpower, 2003)

01/118 L. POZZI, The coefficient of relative risk aversion: a Monte Carlo study investigating small sample estimator problems, October 2001, 21 p. (forthcoming in Economic Modelling, 2003). 
01/119 N. GOBBIN, B. VAN AARLE, Fiscal Adjustments and Their Effects during the Transition to the EMU, October 2001, 28 p. (published in Public Choice, 2001).

01/120 A. DE VOS, D. BUYENS, R. SCHALK, Antecedents of the Psychological Contract: The Impact of Work Values and Exchange Orientation on Organizational Newcomers' Psychological Contracts, November 2001, 41 p.

01/121 A. VAN LANDSCHOOT, Sovereign Credit Spreads and the Composition of the Government Budget, November 2001, $29 \mathrm{p}$.

01/122 K. SCHOORS, The fate of Russia's former state banks: Chronicle of a restructuring postponed and a crisis foretold, November 2001, 54 p. (published in Europe-Asia Studies, 2003)

01/123 J. ALBRECHT, D. FRANÇOIS, K. SCHOORS, A Shapley Decomposition of Carbon Emissions without Residuals, December 2001, 21 p. (published in Energy Policy, 2002).

01/124 T. DE LANGHE, H. OOGHE, Are Acquisitions Worthwhile? An Empirical Study of the Post-Acquisition Performance of Privately Held Belgian Companies Involved in Take-overs, December 2001, 29 p.

01/125 L. POZZI, Government debt, imperfect information and fiscal policy effects on private consumption. Evidence for 2 high debt countries, December 2001, 34 p.

02/126 G. RAYP, W. MEEUSEN, Social Protection Competition in the EMU, January 2002, 20 p.

02/127 S. DE MAN, P. GEMMEL, P. VLERICK, P. VAN RIJK, R. DIERCKX, Patients' and personnel's perceptions of service quality and patient satisfaction in nuclear medicine, January 2002, 21 p.

02/128 T. VERBEKE, M. DE CLERCQ, Environmental Quality and Economic Growth, January 2002, 48 p.

02/129 T. VERBEKE, M. DE CLERCQ, Environmental policy, policy uncertainty and relocation decisions, January $2002,33 \mathrm{p}$.

02/130 W. BRUGgemAN, V. DECOENE, An Empirical Study of the Influence of Balanced Scorecard-Based Variable Remuneration on the Performance Motivation of Operating Managers, January 2002, $19 \mathrm{p}$.

02/131 B. CLARYSSE, N. MORAY, A. HEIRMAN, Transferring Technology by Spinning off Ventures: Towards an empirically based understanding of the spin off process, January $2002,32 \mathrm{p}$.

02/132 H. OOGHE, S. BALCAEN, Are Failure Prediction Models Transferable From One Country to Another? An Empirical Study Using Belgian Financial Statements, February 2002, 42 p.

02/133 M. VANHOUCKE, E. DEMEULEMEESTER, W. HERROELEN, Discrete Time/Cost Trade-offs in Project scheduling with Time-Switch Constraints? February 2002, 23 p. (published in Journal of the Operational Research Society, 2002)

02/134 C. MAYER, K. SCHOORS, Y. YAFEH, Sources of Funds and Investment Activities of Venture Capital Funds: Evidence from Germany, Israel, Japan and the UK?, February 2002, 31 p.

02/135 K. DEWETTINCK, D. BUYENS, Employment implications of downsizing strategies and reorientation practices: an empirical exploration, February 2002, 22 p.

02/136 M. DELOOF, M. DE MAESENEIRE, K. INGHELBRECHT, The Valuation of IPOs by Investment Banks and the Stock Market: Empirical Evidence, February 2002, 24 p.

02/137 P. EVERAERT, W. BRUggemAN, Cost Targets and Time Pressure during New Product Development, March 2002, 21 p. (published in International Journal of Operations and Production Management, 2002).

02/138 D. O'NEILL, O. SWEETMAN, D. VAN DE GAER, The impact of cognitive skills on the distribution of the blackwhite wage gap, March 2002, 14 p.

02/139 W. DE MAESENEIRE, S. MANIGART, Initial returns: underpricing or overvaluation? Evidence from Easdaq and EuroNM, March 2002, 36 p. 


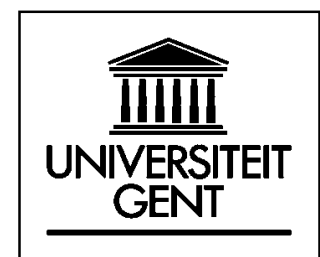

02/140 K. SCHOORS, Should the Central and Eastern European accession countries adopt the EURO before or after accession? March 2002, 29p. (published in Economics of Planning, 2002).

02/141 D. VERHAEST, E. OMEY, Overeducation in the Flemish Youth Labour Market, March 2002, 39p.

02/142 L. CUYVERS, M. DUMONT, G. RAYP, K. STEVENS, Wage and Employment Effects in the EU of International Trade with the Emerging Economies, April 2002, 24 p. (forthcoming in Weltwirtschaftliches Archiv, 2003).

02/143 M. GEUENS, P. DE PELSMACKER, The Role of Humor in the Persuasion of Individuals Varying in Need for Cognition, April 2002, 19 p. (published in Advances in Consumer Research, 2002).

02/144 M. VANHOUCKE, E. DEMEULEMEESTER, W. HERROELEN, Net Present Value Maximization of Projects with Progress Payments, April 2002, 23 p. (published in European Journal of Operational Research, 2003)

02/145 E. SCHOKKAERT, D. VAN DE GAER, F. VANDENBROUCKE, Responsibility-sensitive egalitarianism and optimal linear income taxation, April 2002, 37p.

02/146 J. ANNAERT, J. CROMBEZ, B. SPINEL, F. VAN HOLLE, Value and size effect: Now you see it, now you don't, May 2002, $31 \mathrm{p}$.

02/147 N. HOUTHOOFD, A. HEENE, The quest for strategic groups: Overview, and suggestions for future research, July 2002, 22 p.

02/148 G. PEERSMAN, The transmission of monetary policy in the Euro area: Are the effects different across countries?, July 2002, $35 \mathrm{p}$.

02/149 G. PEERSMAN, F. SMETS, The industry effects of monetary policy in the Euro area, July 2002, $30 \mathrm{p}$.

02/150 J. BOUCKAERT, G. DHAENE, Inter-Ethnic Trust and Reciprocity: Results of an Experiment with Small Business Entrepreneurs, July 2002, $27 \mathrm{p}$.

02/151 S. GARRÉ, I. DE BEELDE, Y. LEVANT, The impact of accounting differences between France and Belgium, August 2002, 28 p. (published in French in Comptabilité - Controle - Audit, 2002)

02/152 R. VANDER VENNET, Cross-border mergers in European banking and bank efficiency, September 2002, 42 p.

02/153 K. SCHOORS, Financial regulation in Central Europe: the role of reserve requirements and capital rules, September 2002, 22 p.

02/154 B. BAESENS, G. VERStRAeten, D. VAN DEN POEL, M. EGMONT-PETERSEN, P. VAN KENHOVE, J. VANTHIENEN, Bayesian Network Classifiers for Identifying the Slope of the Customer Lifecycle of Long-Life Customers, October 2002, 27 p. (forthcoming in European Journal of Operational Research, 2003).

02/155 L. POZZI, F. HEYLEN, M. DOSSCHE, Government debt and the excess sensitivity of private consumption to current income: an empirical analysis for OECD countries, October 2002, $19 \mathrm{p}$.

02/156 D. O'NEILL, O. SWEETMAN, D. VAN DE GAER, Consequences of Specification Error for Distributional Analysis With an Application to Intergenerational Mobility, November 2002, 35 p.

02/157 K. SCHOORS, B. VAN DER TOL, Foreign direct investment spillovers within and between sectors: Evidence from Hungarian data, November 2002, 29 p.

02/158 L. CUYVERS, M. DUMONT, G. RAYP, K. STEVENS, Home Employment Effects of EU Firms' Activities in Central and Eastern European Countries, November 2002, 25 p.

02/159 M. VANHOUCKE, Optimal due date assignment in project scheduling, December 2002, $18 \mathrm{p}$. 


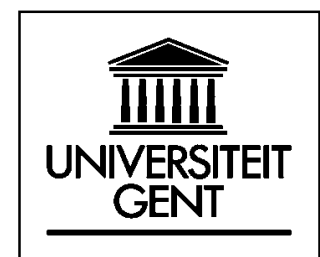

02/160 J. ANNAERT, M.J.K. DE CEUSTER, W. VANHYFTE, The Value of Asset Allocation Advice. Evidence from the Economist's Quarterly Portfolio Poll, December 2002, 35p.

02/161 M. GEUENS, P. DE PELSMACKER, Developing a Short Affect Intensity Scale, December 2002, 20 p. (published in Psychological Reports, 2002).

02/162 P. DE PELSMACKER, M. GEUENS, P. ANCKAERT, Media context and advertising effectiveness: The role of context appreciation and context-ad similarity, December 2002, 23 p. (published in Journal of Advertising, 2002).

03/163 M. GEUENS, D. VANTOMME, G. GOESSAERT, B. WEIJTERS, Assessing the impact of offline URL advertising, January 2003,20 p.

03/164 D. VAN DEN POEL, B. LARIVIĖRE, Customer Attrition Analysis For Financial Services Using Proportional Hazard Models, January 2003, 39 p. (forthcoming in European Journal of Operational Research, 2003)

03/165 P. DE PELSMACKER, L. DRIESEN, G. RAYP, Are fair trade labels good business ? Ethics and coffee buying intentions, January 2003, 20 p.

03/166 D. VANDAELE, P. GeMMEL, Service Level Agreements - Een literatuuroverzicht, Januari 2003,31 p. (forthcoming in Tijdschrift voor Economie en Management, 2003).

03/167 P. VAN KENHOVE, K. DE WULF AND S. STEENHAUT, The relationship between consumers' unethical behavior and customer loyalty in a retail environment, February 2003, 27 p.

03/168 P. VAN KENHOVE, K. DE WULF, D. VAN DEN POEL, Does attitudinal commitment to stores always lead to behavioural loyalty? The moderating effect of age, February 2003, 20 p.

03/169 E. VERHOFSTADT, E. OMEY, The impact of education on job satisfaction in the first job, March $2003,16 \mathrm{p}$.

03/170 S. DOBBELAERE, Ownership, Firm Size and Rent Sharing in a Transition Country, March 2003,26 p. (forthcoming in Labour Economics, 2004)

03/171 S. DOBBELAERE, Joint Estimation of Price-Cost Margins and Union Bargaining Power for Belgian Manufacturing, March 2003, $29 \mathrm{p}$.

03/172 M. DUMONT, G. RAYP, P. WILLEMÉ, O. THAS, Correcting Standard Errors in Two-Stage Estimation Procedures with Generated Regressands, April 2003, 12 p.

03/173 L. POZZI, Imperfect information and the excess sensitivity of private consumption to government expenditures, April 2003, 25 p.

03/174 F. HEYLEN, A. SCHOLLAERT, G. EVERAERT, L. POZZI, Inflation and human capital formation: theory and panel data evidence, April 2003, 24 p.

03/175 N.A. DENTCHEV, A. HEENE, Reputation management: Sending the right signal to the right stakeholder, April 2003, 26 p.

03/176 A. WILLEM, M. BUELENS, Making competencies cross business unit boundaries: the interplay between inter-unit coordination, trust and knowledge transferability, April 2003, 37 p.

03/177 K. SCHOORS, K. SONIN, Passive creditors, May 2003, 33 p.

03/178 W. BUCKINX, D. VAN DEN POEL, Customer Base Analysis: Partial Defection of Behaviorally-Loyal Clients in a Non-Contractual FMCG Retail Setting, May 2003, 26 p.

03/179 H. OOGHE, T. DE LANGHE, J. CAMERLYNCK, Profile of multiple versus single acquirers and their targets : a research note, June 2003, $15 \mathrm{p}$. 


\begin{tabular}{|c|c|c|c|}
\hline 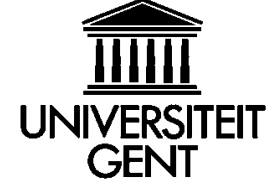 & $\begin{array}{l}\text { FACULTEIT ECONOMIE EN BEDRIJFSKUNDE } \\
\text { HOVENIERSBERG } 24 \\
9000 \text { GENT }\end{array}$ & $\begin{array}{l}\text { Tel. } \\
\text { Fax. }\end{array}$ & $\begin{array}{l}: 32-(0) 9-264.34 .61 \\
: 32-(0) 9-264.35 .92\end{array}$ \\
\hline WORKING & APER SERIES & & 10 \\
\hline
\end{tabular}

03/180 M. NEYT, J. ALBRECHT, B. CLARYSSE, V. COCQUYT, The Cost-Effectiveness of Herceptin® in a Standard Cost Model for Breast-Cancer Treatment in a Belgian University Hospital, June 2003, 20 p.

03/181 M. VANHOUCKE, New computational results for the discrete time/cost trade-off problem with time-switch constraints, June 2003, 24 p.

03/182 C. SCHLUTER, D. VAN DE GAER, Mobility as distributional difference, June 2003, 22 p.

03/183 B. MERLEVEDE, Reform Reversals and Output Growth in Transition Economies, June 2003, 35 p.

03/184 G. POELS, Functional Size Measurement of Multi-Layer Object-Oriented Conceptual Models, June 2003, 13 p. (forthcoming in Lecture Notes in Computer Science, 2003)

03/185 A. VEREECKE, M. STEVENS, E. PANDELAERE, D. DESCHOOLMEESTER, A classification of programmes and its managerial impact, June 2003, 11 p. (forthcoming in International Journal of Operations and Production Management, 2003)

03/186 S. SteEnhAUT, P. VANKEnHOVE, Consumers' Reactions to "Receiving Too Much Change at the Checkout", July 2003,28 p.

03/187 H. OOGHE, N. WAEYAERT, Oorzaken van faling en falingspaden: Literatuuroverzicht en conceptueel verklaringsmodel, July $2003,35 \mathrm{p}$.

03/188 S. SCHILLER, I. DE BEELDE, Disclosure of improvement activities related to tangible assets, August 2003, $21 \mathrm{p}$.

03/189 L. BAELE, Volatility Spillover Effects in European Equity Markets, August 2003, 73 p.

03/190 A. SCHOLLAERT, D. VAN DE GAER, Trust, Primary Commodity Dependence and Segregation, August 2003,18 p

03/191 D. VAN DEN POEL, Predicting Mail-Order Repeat Buying: Which Variables Matter?, August 2003, 25 p.

03/192 T. VERBEKE, M. DE CLERCQ, The income-environment relationship: Does a logit model offer an alternative empirical strategy?, September 2003, 32 p.

03/193 S. HERMANNS, H. OOGHE, E. VAN LAERE, C. VAN WYMEERSCH, Het type controleverslag: resultaten van een empirisch onderzoek in België, September 2003, 18 p.

03/194 A. DE VOS, D. BUYENS, R. SCHALK, Psychological Contract Development during Organizational Socialization: Adaptation to Reality and the Role of Reciprocity, September 2003, 42 p.

03/195 W. BUCKINX, D. VAN DEN POEL, Predicting Online Purchasing Behavior, September 2003, 43 p. 